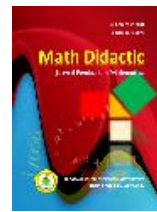

MATH DIDACTIC: JURNAL PENDIDIKAN MATEMATIKA

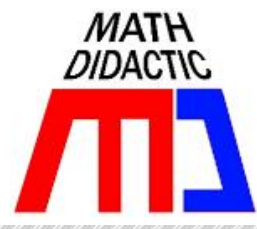

Tersedia Daring pada https://jurnal.stkipbjm.ac.id/index.php/math

\author{
PENGARUH KEMAMPUAN AKADEMIK DAN PEDAGOGIK TERHADAP \\ KETERAMPILAN DASAR MENGAJAR CALON GURU MATEMATIKA DALAM \\ PENGAJARAN MIKRO
}

\title{
THE EFFECT OF ACADEMIC AND PEDAGOGIC COMPETENCES ON BASIC TEACHING SKILLS OF MATHEMATICS TEACHER CANDIDATES IN MICRO TEACHING
}

\author{
Kurnia Putri Sepdikasari Dirgantoro \\ Universitas Pelita Harapan \\ kurnia.dirgantoro@uph.edu
}

\begin{abstract}
Abstrak: Keterampilan mengajar merupakan salah satu keterampilan dasar yang harus dikuasai oleh seorang guru. Oleh karenanya, mahasiswa calon guru perlu terus menerus melatih diri untuk mengembangkan keterampilan mengajarnya. Salah satu cara yang diusahakan adalah melalui pengajaran mikro pada mata kuliah PSAP (Perencanaan, Strategi, Asesmen, Pembelajaran) Matematika. Tujuan penelitian ini adalah untuk mengetahui kontribusi dari kemampuan akademik dan pedagogik mahasiswa calon guru terhadap keterampilan dasar mengajar mereka dalam pengajaran mikro. Subjek penelitian terdiri dari 56 mahasiswa prodi Pendidikan Matematika Universitas Pelita Harapan angkatan 2017. Penelitian ini merupakan penelitian korelasional dan analisis regresi linear sederhana. Instrumen yang digunakan dalam pengumpulan data meliputi rubrik pengajaran mikro, arsip nilai mahasiswa, dan kuesioner. Hasil penelitian ini adalah: (1) terdapat korelasi yang signifikan antara kemampuan akademik dan keterampilan dasar mengajar; (2) terdapat pengaruh yang signifikan dari kemampuan akademik terhadap keterampilan dasar mengajar; (3) terdapat korelasi yang signifikan antara kemampuan pedagogik dan keterampilan dasar mengajar; serta (4) terdapat pengaruh yang signifikan dari kemampuan pedagogik terhadap keterampilan dasar mengajar. Ini berarti, mata kuliah pedagogi dan konten dasar matematika yang diberikan sudah sesuai dengan kebutuhan mahasiswa.
\end{abstract}

Kata Kunci: kemampuan akademik, kemampuan pedagogik, keterampilan dasar mengajar, pengajaran mikro

\begin{abstract}
Teaching skills are one of the basic skills that must be mastered by a teacher. Therefore, student teacher need to continuously train themselves to develop their teaching skills. One way that is attempted is through micro teaching in the PSAL (Planning, Strategy, Assessment, Learning) Mathematics course. The purpose of this study was to determine the contribution of the academic and pedagogic competences of student teacher to the basic skills of teaching them in micro teaching. The research subjects are 56 students of University of Pelita Harapan Mathematics Education Study Program class of 2017. This study is a correlational study and simple linear regression analysis. The instruments used in data collection include the rubric of micro teaching, archives of student score, and questionnaires. The results of this study are: (1) there is a significant correlation between academic abilities and basic teaching skills; (2) there is a significant effect of academic ability on basic teaching skills; (3) there is a significant correlation between pedagogic abilities and basic teaching skills; and (4) there is a significant effect of pedagogic skills on basic teaching skills. The conclusion is pedagogic and basic mathematics courses already in accordance with the needs of students.
\end{abstract}

Keywords: academic competence, pedagogic competence, basic teaching skills, micro teaching

Cara Sitasi: Dirgantoro, K.P.S. (2019). Pengaruh kemampuan akademik dan pedagogik terhadap keterampilan dasar mengajar calon guru matematika dalam pengajaran mikro. Math Didactic: Jurnal Pendidikan Matematika, 5(2), 123-132. https://doi.org/10.33654/math.v5.i2.604

Submitted: May 9, 2019

Revised: June 13, 2019

Published: August 30, 2019

Available Online Since: July 23, 2019

https://doi.org/10.33654/math.v5i2.604

Math Didactic: Jurnal Pendidikan Matematika 
Keterampilan mengajar merupakan salah satu keterampilan dasar yang diperlukan oleh mahasiswa Fakultas Ilmu Pendidikan yang nantinya akan menjadi seorang guru (Siswanto, 2010). Dengan memiliki kemampuan mengajar yang baik, maka mahasiswa yang nantinya akan menjadi guru dapat mengemas pembelajaran dengan lebih menarik sehingga dapat meningkatkan minat dan motivasi siswa dalam belajar. Begitu pula dengan mahasiswa prodi Pendidikan Matematika. Apalagi matematika sering kali menjadi mata pelajaran yang dianggap sulit dan menakutkan oleh siswa (Siregar, 2017). Oleh sebab itu, guru matematika perlu mengikis pandangan tersebut sedikit demi sedikit dengan berupaya membuat pembelajaran matematika menjadi semakin bermakna dan menyenangkan. Guna mencapai hal tersebut perlu kemampuan dan usaha yang besar dari seorang guru. Karenanya mahasiswa calon guru perlu dilatih untuk dapat menguasai bagaimana merencanakan, memilih strategi dan asesmen yang tepat dalam pembelajaran matematika.

Keterampilan dasar mengajar mahasiswa dapat dilatih melalui mata kuliah PSAP (Perencanaan, Strategi, Asesmen Pembelajaran) Matematika. Adapun di Fakultas Ilmu Pendidikan Universitas Pelita Harapan, mahasiswa prodi Pendidikan Matematika akan mengikuti 2 mata kuliah PSAP Matematika, yaitu PSAP Matematika Sekolah Dasar dan PSAP Matematika Sekolah Menengah. Dengan diberikannya kedua mata kuliah tersebut diharapkan mahasiswa akan siap menjadi seorang guru matematika, baik di sekolah dasar maupun di sekolah menengah. PSAP Matematika Sekolah Dasar diberikan di semester 4, sedangkan PSAP Matematika Sekolah Menengah diberikan di semester 5. Mata kuliah PSAP diberikan setelah mahasiswa selesai mengikuti rangkaian mata kuliah pedagogi, namun sebelum mahasiswa melaksanakan PPL di semester 7. Di dalam mata kuliah PSAP Matematika, mahasiswa kembali diingatkan dan dikuatkan mengenai bagaimana proses dalam merencanakan, menentukan strategi, membuat asesmen dalam pembelajaran matematika yang sebelumnya sudah dipelajari dalam mata kuliah Pedagogi 1, Pedagogi 2, dan Pedagogi 3. Adapun yang menjadi keluaran pada penilaian dalam mata kuliah ini adalah RPP dan pengajaran mikro.

Dalam pembelajaran mikro, kriteria penilaian yang dilakukan berkenaan dengan keterampilan dasar mengajar mahasiswa. Suwarno, et al. (dalam Wijarini \& Ilma, 2017) menyatakan bahwa keterampilan dasar mengajar yang perlu dimiliki oleh seorang guru sebagai pendidik profesional meliputi: a) keterampilan menyusun skenario, b) keterampilan membuka dan menutup pembelajaran, c) keterampilan menjelaskan materi, d) keterampilan bertanya, e) keterampilan memberikan penguatan, f) keterampilan menggunakan media, g) keterampilan mengadakan variasi, h) keterampilan membimbing diskusi, i) keterampilan melakukan penilaian, dan j) keterampilan mengelola kelas. Adapun di FIP UPH, keterampilan dasar mengajar mahasiswa yang akan diamati dalam pengajaran mikro adalah keterampilan dalam: 1) pembukaan, 2) strategi/metode mengajar, 3) pemahaman materi, konsep dan isi pelajaran, 4) media presentasi/alat dan bahan belajar/alat peraga, 5) penguasaan/pengelolaan/manajemen kelas, 6) berbicara, serta 7) penutup.

Pengajaran mikro dapat diartikan sebagai cara latihan keterampilan keguruan atau praktik mengajar dalam lingkup kecil/terbatas (Asril, 2016). Gagasan mengenai pengajaran mikro (micro teaching) muncul 
pertama kali pada tahun 1963 di Universitas Stanford sebagai sebuah metode untuk mengembangkan keterampilan mengajar (Mahmud \& Rawshon, 2013). Dengan adanya pengajaran mikro, mahasiswa dilatih untuk dapat merencanakan dan menghasilkan pembelajaran dengan melihat karakteristik siswa dan materi yang akan diajarkan. Karakteristik pembelajaran matematika di sekolah dasar akan berbeda dengan di sekolah menengah, baik dari segi siswa maupun kurikulum. Oleh karena itu pendekatan/metode/strategi pembelajaran yang digunakan pun seharusnya berbeda. Hasil penelitian Mergler \& Tangen (2010) menyatakan bahwa pengajaran mikro dapat meningkatkan keberhasilan mengajar mahasiswa pasca sarjana sebagai calon guru (pre-service teacher). Sejalan dengan hal tersebut, Mahmud \& Rawshon (2013) menyatakan bahwa berdasarkan percobaan berulang terdapat peningkatan yang luar biasa dalam keterampilan mengajar subjek yang melakukan pengajaran mikro dalam suatu kurun waktu tertentu. Selain itu, pengajaran mikro pun dapat membantu meningkatkan kepercayaan diri dan mengatasi kecemasan para calon guru (Şen, 2009). Ini berarti pengajaran mikro menjadi sarana bagi mahasiswa untuk dapat melatih keterampilan mengajar secara formal.

Dalam proses pembelajaran, guru tidak hanya membutuhkan kemampuan pedagogik saja, pemahaman terhadap bidang studi yang akan diajarkan juga tidak kalah penting. Barlian (2013) menyatakan bahwa salah satu faktor penting yang perlu diperhatikan dalam menyusun pelaksanaan pembelajaran adalah materi yang akan diajarkan. Ini berarti, bagi seorang guru matematika, pemahaman terhadap konsep matematika sangat diperlukan tidak hanya sebatas keterampilan prosedural saja. Guru tidak hanya berperan sebagai penyampai materi saja namun juga diharapkan mampu membuat landasan konsep yang kokoh bagi siswa, khususnya bagi siswa sekolah dasar agar ke depannya siswa tidak kesulitan ketika materi yang didapat semakin kompleks dan abstrak. Karim (2011) menyatakan bahwa "pembelajaran matematika di sekolah dasar merupakan dasar bagi penerapan konsep matematika pada jenjang berikutnya." Pemahaman guru terhadap materi yang dijelaskan dapat berdampak pada bagaimana cara guru menjelaskan materi tersebut. Pada saat menjelaskan materi, guru perlu menimbulkan rasa ingin tahu pada diri siswa agar siswa mau terus belajar (Raharja, Wibhawa, \& Lukas, 2018). Ini berarti kemampuan akademik mahasiswa pun menjadi faktor utama yang diperlukan agar mahasiswa dapat menjadi guru matematika yang memiliki kompetensi unggul.

Jika diperhatikan, tidak terdapat mata kuliah khusus yang membahas materi matematika sekolah dasar dalam kurikulum matematika perguruan tinggi. Namun mata kuliah konten matematika dasar semestinya dapat menjadi bekal bagi mahasiswa untuk semakin memahami dasar-dasar matematika sehingga mahasiswa dapat mengajar materi matematika sekolah dasar dengan baik. Adapun mata kuliah konten dasar yang diberikan adalah Kalkulus 1, Kalkulus 2, Aljabar Linear dan Geometri.

Berdasarkan latar belakang tersebut maka yang menjadi tujuan penelitian ini adalah: (1) mengetahui apakah terdapat korelasi antara kemampuan akademik dan keterampilan dasar mengajar mahasiswa dalam pengajaran mikro; (2) mengetahui bagaimana pengaruh kemampuan akademik terhadap keterampilan dasar mengajar mahasiswa; (3) mengetahui apakah terdapat 
korelasi antara kemampuan pedagogik dan keterampilan dasar mengajar mahasiswa dalam pengajaran mikro; (4) mengetahui bagaimana pengaruh kemampuan pedagogik terhadap keterampilan dasar mengajar mahasiswa.

Hasil penelitian ini diharapkan dapat menjadi masukan bagi universitas untuk melihat apakah mata kuliah pedagogi dan konten dasar matematika yang diberikan sudah sesuai bagi kebutuhan mengajar mahasiswa sebagai guru matematika, khususnya di jenjang sekolah dasar.

\section{Metode Penelitian}

Penelitian ini merupakan penelitian kuantitatif yang terdiri dari penelitian korelasional dan regresi linear sederhana. Penelitian korelasional bertujuan melihat hubungan antara satu atau beberapa variabel dengan satu atau beberapa variabel yang lain (Yusuf, 2014). Dalam penelitian ini yang akan diamati adalah korelasi antara kemampuan akademik dan kemampuan pedagogik dengan keterampilan dasar mengajar. Sementara regresi linear sederhana merupakan teknik yang digunakan untuk melihat hubungan antara satu variabel terikat dan satu variabel bebas di mana variabel bebas dianggap mempengaruhi variabel terikat (Suyono, 2018). Regresi linear sederhana digunakan untuk melihat pengaruh dari kemampuan akademik dan kemampuan pedagogik terhadap keterampilan dasar mengajar.

\section{Subjek Penelitian}

Subjek penelitian ini adalah mahasiswa

prodi Pendidikan Matematika FIP UPH angkatan 2017 yang berjumlah 56 orang, yang terdiri dari 21 mahasiswa laki-laki dan 35 mahasiswa perempuan.

\section{Tempat dan Waktu}

Penelitian ini dilaksanakan di Universitas Pelita Harapan yang berlokasi di Jl. M.H. Thamrin Boulevard, Kelapa Dua, Karawaci, Kota Tangerang, Banten 15810, Indonesia. Waktu pelaksanaan penelitian ini adalah di semester genap tahun ajaran 2018/2019.

\section{Pengumpulan Data}

Pengumpulan data dilakukan di sepanjang penelitian. Data mengenai kemampuan akademik dan kemampuan pedagogik dikumpulkan dari arsip nilai yang telah ada. Adapun data mengenai kemampuan akademik diperoleh dari rata-rata nilai akhir mahasiswa dalam mata kuliah Kalkulus 1, Geometri, Kalkulus 2, dan Aljabar Linear. Data mengenai kemampuan pedagogik diperoleh dari rata-rata nilai akhir mahasiswa dalam mata kuliah Pedagogi 1, Pedagogi 2, dan Pedagogi 3. Sementara data mengenai kemampuan dasar mengajar dikumpulkan sepanjang proses perkuliahan PSAP Matematika SD saat mahasiswa melakukan pengajaran mikro (micro teaching).

\section{Instrumen Penelitian}

Instrumen penelitian yang digunakan dalam penelitian ini adalah rubrik penilaian micro teaching yang telah divalidasi oleh dosen ahli dan digunakan untuk semua mata kuliah PSAP di FIP UPH. Adapun hasil validitas untuk masing-masing pernyataan berkisar pada jenjang sedang dan tinggi, sedangkan reliabilitasnya tergolong sedang. 


\section{Hasil Penelitian dan Pembahasan}

\section{Hasil}

Berikut disajikan data mengenai kemampuan akademik, kemampuan pedagogik, dan keterampilan dasar mengajar mahasiswa program studi Pendidikan Matematika FIP UPH angkatan 2017.

Tabel 1. Deskriptif Skor Mahasiswa

\begin{tabular}{lccccc}
\hline Skor & N & $\begin{array}{l}\text { Rata- } \\
\text { rata }\end{array}$ & $\boldsymbol{s}$ & $\boldsymbol{x}_{\boldsymbol{m}}$ & $\boldsymbol{x}_{\boldsymbol{m}}$ \\
\hline $\begin{array}{l}\text { Kemampuan } \\
\text { Akademik }\end{array}$ & 556 & 77,82 & 9,31 & 57,55 & 93,56 \\
$\begin{array}{l}\text { Kemampuan } \\
\text { Pedagogik }\end{array}$ & 556 & 84,67 & 2,59 & 78,84 & 91,92 \\
$\begin{array}{l}\text { Keterampilan } \\
\text { Dasar Mengajar }\end{array}$ & 556 & 80,34 & 5,78 & 67,90 & 89,30 \\
\hline
\end{tabular}

Sebelum melakukan uji korelasional, maka masing-masing data skor diuji kenormalannya terlebih dahulu.

\section{Uji normalitas}

Untuk uji normalitas masing-masing skor, digunakan uji statistik Shapiro-Wilk karena jumlah data yang lebih dari 30 buah dengan taraf signifikansi 5\%. Dengan bantuan program SPSS 22 diperoleh hasil sebagai berikut.

Tabel 2. Uji Normalitas

\begin{tabular}{llllllll}
\hline & \multicolumn{3}{c}{$\begin{array}{l}\text { Kolmogorov- } \\
\text { Smirnova }\end{array}$} & & & & \\
& & & & & & \\
& Statistic & f & Sig. & Statistic & f & Sig. \\
\hline $\begin{array}{l}\text { Skor Kemampuan } \\
\text { Akademik }\end{array}$ & .116 & 56 & .059 & .962 & 56 & .079 \\
$\begin{array}{l}\text { Skor Kemampuan } \\
\text { Pedagogik }\end{array}$ & .088 & 56 & $.200^{*}$ & .984 & 56 & .647 \\
$\begin{array}{l}\text { Skor Keterampilan } \\
\text { Dasar Mengajar }\end{array}$ & .209 & 56 & .000 & .933 & 56 & .004 \\
$\begin{array}{l}\text { *. This is a lower bound of the true significance. } \\
\text { a. Lilliefors Significance Correction }\end{array}$ & & & & \\
\hline
\end{tabular}

Berdasarkan Tabel 2 dapat dilihat bahwa nilai signifikasi atau probabilitas dari skor kemampuan akademik dan skor kemampuan pedagogik adalah 0,079 dan 0,647. Ini berarti kedua kelompok skor tersebut berdistribusi normal. Sementara itu skor keterampilan dasar mengajar memiliki nilai signifikansi atau probabilitas sebesar 0,004, artinya skor keterampilan dasar mengajar tidak berdistribusi normal. Data tidak berdistribusi normal dikarenakan terbatasnya jumlah nilai yang berbeda. Hal ini disebabkan kriteria penilaian menggunakan rubrik sehingga membatasi perbedaan nilai. Oleh karena itu untuk uji korelasi akan dilakukan uji non parametrik dengan menggunakan uji Spearman.

\section{Korelasi antara kemampuan akademik dan keterampilan dasar mengajar}

Berikut merupakan hasil uji korelasi dengan bantuan program SPSS 22.

Tabel 3. Hasil Uji Korelasional Kemampuan Akademik dan Keterampilan Dasar Mengajar

\begin{tabular}{|c|c|c|c|c|}
\hline & & & $\begin{array}{l}\text { Skor } \\
\text { Kemampuan } \\
\text { Akademik }\end{array}$ & $\begin{array}{l}\text { Skor } \\
\text { Keterampilan } \\
\text { Dasar } \\
\text { Mengajar }\end{array}$ \\
\hline \multirow[t]{6}{*}{$\begin{array}{l}\text { Spearman's } \\
\text { rho }\end{array}$} & $\begin{array}{l}\text { Skor } \\
\text { Kemampuan }\end{array}$ & $\begin{array}{l}\text { Correlation } \\
\text { Coefficient }\end{array}$ & 1.000 & $.554^{* *}$ \\
\hline & Akademik & Sig.(2-tailed) & . & .000 \\
\hline & & $\mathrm{N}$ & 56 & 56 \\
\hline & $\begin{array}{l}\text { Skor } \\
\text { Keterampilan }\end{array}$ & $\begin{array}{l}\text { Correlation } \\
\text { Coefficient }\end{array}$ & $.554^{* *}$ & 1.000 \\
\hline & $\begin{array}{l}\text { Dasar } \\
\text { Mengajar }\end{array}$ & $\begin{array}{l}\text { Sig. }(2- \\
\text { tailed })\end{array}$ & .000 & . \\
\hline & & $\mathrm{N}$ & 56 & 56 \\
\hline
\end{tabular}

Dari tabel di atas dapat dilihat bahwa nilai Sig. (2-tailed) yang diperoleh adalah 0,000. Ini berarti ada korelasi yang signifikan antara skor kemampuan akademik dan skor keterampilan dasar mengajar. 


\section{Pengaruh kemampuan akademik terhadap keterampilan dasar mengajar}

Berikut merupakan hasil pengolahan data dengan bantuan program SPSS 22 .

$\begin{gathered}\text { Tabel 4. Uji Pengaruh Kemampuan Akademik } \\
\text { terhadap Keterampilan Dasar Mengajar }\end{gathered}$
\begin{tabular}{|cccllll}
\multicolumn{2}{c}{ Model } & Sum of Squares & $d f$ & Mean Square & F & Sig. \\
\hline Regression & 628.876 & 1 & 628.876 & 28.170 & $.000^{\mathrm{b}}$ \\
Residual & 1205.503 & 54 & 22.324 & & \\
Total & 1834.378 & 55 & & & \\
\hline
\end{tabular}

a. Dependent Variable: Skor Keterampilan Dasar Mengajar

b. Predictors: (Constant), Skor Kemampuan Akademik

Tabel di atas memperlihatkan Nilai Sig. 0,000, artinya terdapat pengaruh yang signifikan dari kemampuan akademik terhadap keterampilan dasar mengajar.

Lebih lanjut, hasil kuesioner mahasiswa ketika ditanya: "Menurut Anda apakah mata kuliah konten matematika dasar (Kalkulus 1, Kalkulus 2, Geometri, dan Aljabar Linear) membantu Anda dalam melakukan micro teaching dalam PSAP Matematika SD?"dapat dilihat dalam diagram berikut.

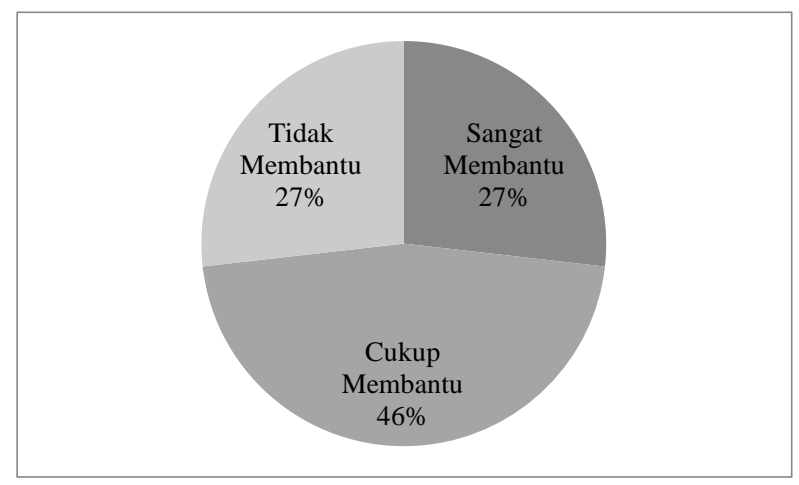

Gambar 1. Diagram Respon Mahasiswa Mengenai Mata Kuliah Konten Dasar Matematika

\section{Korelasi antara skor kemampuan pedagogik dan skor keterampilan dasar mengajar}

Berikut merupakan hasil pengolahan data dengan bantuan program SPSS 22.
Tabel 5. Uji Korelasional Kemampuan Pedagogik dan Keterampilan Dasar Mengajar

\begin{tabular}{|c|c|c|c|c|}
\hline & & & $\begin{array}{l}\text { Skor } \\
\text { Kemampuan } \\
\text { Pedagogik }\end{array}$ & $\begin{array}{l}\text { Skor } \\
\text { Keterampilan } \\
\text { Dasar } \\
\text { Mengajar }\end{array}$ \\
\hline \multirow[t]{6}{*}{$\begin{array}{l}\text { Spearman's } \\
\text { rho }\end{array}$} & $\begin{array}{l}\text { Skor } \\
\text { Kemampuan }\end{array}$ & $\begin{array}{l}\text { Correlation } \\
\text { Coefficient }\end{array}$ & 1.000 & $.350^{* *}$ \\
\hline & Pedagogik & Sig.(2-tailed) & . & .008 \\
\hline & & $\mathrm{N}$ & 56 & 56 \\
\hline & $\begin{array}{l}\text { Skor } \\
\text { Keterampilan }\end{array}$ & $\begin{array}{l}\text { Correlation } \\
\text { Coefficient }\end{array}$ & $.350^{* *}$ & 1.000 \\
\hline & $\begin{array}{l}\text { Dasar } \\
\text { Mengajar }\end{array}$ & $\begin{array}{l}\text { Sig. }(2- \\
\text { tailed })\end{array}$ & .008 & . \\
\hline & & $\mathrm{N}$ & 56 & 56 \\
\hline
\end{tabular}

Dari tabel di atas dapat dilihat bahwa nilai Sig. (2-tailed) yang diperoleh adalah 0,008 . Ini berarti ada korelasi yang signifikan antara skor kemampuan akademik dan skor keterampilan dasar mengajar.

\section{Pengaruh kemampuan pedagogik terhadap keterampilan dasar mengajar}

Berikut merupakan hasil pengolahan data dengan bantuan program SPSS 22 .

Tabel 6. Uji Pengaruh Kemampuan Akademik terhadap Keterampilan Dasar Mengajar

\begin{tabular}{lllllll}
\hline Model & Sum of Squares & $d f$ & Mean Square & $F$ & Sig. \\
\hline Regression & 230.479 & 1 & 230.479 & 7.760 & $.007^{\mathrm{b}}$ \\
Residual & 1603.899 & 54 & 29.702 & & \\
Total & 1834.378 & 55 & & & \\
\hline a. Dependent Variable: Skor Keterampilan Dasar Mengajar & \\
b. Predictors: (Constant), Skor Kemampuan Pedagogik &
\end{tabular}

Tabel di atas memperlihatkan Nilai Sig 0,007. Ini berarti terdapat pengaruh yang signifikan dari kemampuan pedagogik terhadap keterampilan dasar mengajar.

Berdasarkan kuesioner, seluruh mahasiswa menyatakan bahwa mata kuliah Pedagogi sangat membantu mahasiswa mempersiapkan diri dalam melaksanakan micro teaching. Adapun hasil kuesioner mahasiswa dapat dilihat pada diagram berikut. 


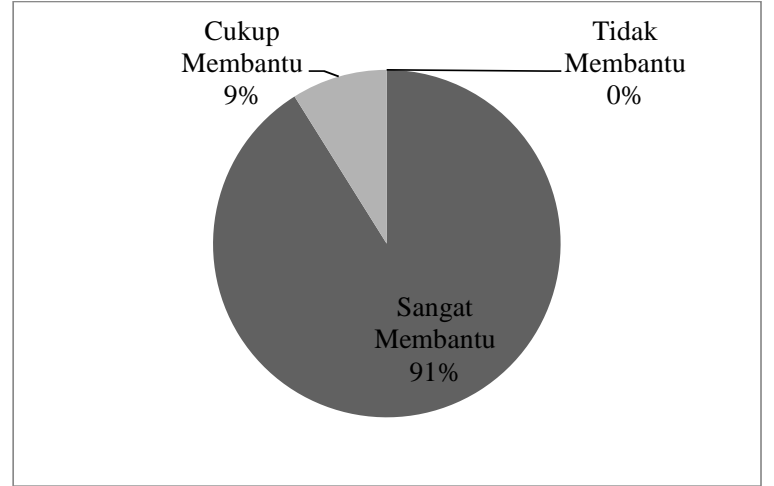

Gambar 2. Diagram Respon Mahasiswa Mengenai Mata Kuliah Pedagogi

\section{Pembahasan}

\section{Kemampuan akademik dan keterampilan dasar mengajar}

Hasil uji korelasi seperti yang dapat dilihat pada Tabel 3 menunjukkan bahwa terdapat korelasi yang signifikan antara skor kemampuan akademik dan keterampilan dasar mengajar dengan koefisien korelasinya sebesar 0,554 . Nilai ini termasuk ke dalam korelasi sedang (Sugiyono, 2014).

Sementara itu, pada Tabel 4 dapat dilihat bahwa terdapat pengaruh yang signifikan dari kemampuan akademik terhadap keterampilan dasar mengajar. Artinya, keberhasilan mahasiswa dalam akademik memberikan pengaruh positif terhadap keberhasilan mahasiswa dalam micro teaching.

Hasil ini sejalan dengan kompetensi profesional yang merupakan salah satu kompetensi yang perlu dimiliki oleh seorang guru. Kompetensi profesional merupakan "kemampuan guru dalam penguasaan materi pembelajaran secara luas dan mendalam yang memungkinkannya membimbing siswa memperoleh kompetensi yang ditetapkan" (Dirgantoro, 2018). Ini berarti pemahaman guru terhadap konsep materi yang akan diajarkannya sangat penting. Ketika guru memiliki pemahaman matematika yang mendalam maka ia tidak akan kesulitan dalam menghubungkan berbagai konsep dalam matematika, juga menghubungkan konsep matematika dengan konsep dari mata pelajaran lain. Hal ini dapat meningkatkan perhatian dan motivasi siswa dalam belajar matematika (Herman, 2010).

Sementara itu berdasarkan Gambar 1, terdapat 16 mahasiswa menyatakan bahwa mata kuliah konten matematika dasar "cukup membantu" dan 15 mahasiswa menyatakan bahwa mata kuliah konten matematika dasar "sangat membantu". Berikut merupakan ringkasan alasan jawaban mahasiswa. Mahasiswa berpendapat bahwa mata kuliah konten matematika dasar: (1) membantu pendalaman materi; (2) melatih cara berpikir menjadi lebih kritis sehingga dapat mengetahui bagaimana cara mengajarkan konsep matematika kepada siswa dengan baik; (3) membantu memahami dasar dari pelajaran dalam matematika SD; (4) beberapa konten maupun topik masih berkaitan, contohnya geometri; (5) konsep atau pemahaman dasar diperoleh saat mengikuti mata kuliah konten dasar matematika membantu dalam menjelaskan materi kepada siswa; (6) mengetahui asal muasal rumus dan teoremanya; (7) membantu cara berpikir sehingga lebih terstruktur dalam melakukan micro teaching; (8) membantu berpikir sistematis; serta (9) mengingatkan konsepkonsep dasar yang seharusnya didapatkan pada waktu SD, sehingga dalam micro teaching pun juga terbantu.

Namun terdapat 15 mahasiswa yang menyatakan bahwa mata kuliah konten matematika dasar "tidak membantu" mereka dalam melaksanakan micro teaching. Berikut merupakan ringkasan alasan jawaban mahasiswa. Mahasiswa berpendapat bahwa mata kuliah konten matematika dasar tidak 
membantu dikarenakan: (1) materi pada mata kuliah konten matematika dasar berbeda dengan matematika SD; (2) materi yang akan diajarkan tidak "setinggi" keempat mata kuliah konten matematika dasar; (3) materi pada mata kuliah konten matematika dasar tidak berhubungan dengan matematika SD; (4) materi matematika SD masih dalam pemahaman dasar; (5) materi yang dibawakan pada saat micro teaching tidak secara langsung berkaitan dengan mata-mata kuliah di atas; (6) materi yang ada pada mata kuliah kalkulus 1 dan 2, geometri dan aljabar linear terlalu tinggi untuk anak tingkat SD; serta (7) materi yang akan diajarkan tidak memiliki korelasi dengan materi pada mata kuliah konten matematika dasar.

Bila diamati, respon/jawaban mahasiswa langsung menghubungkan antara materi yang akan mereka ajarkan dalam micro teaching (matematika SD) dengan materi pada mata kuliah konten matematika dasar. Hal ini menyebabkan mereka berpendapat bahwa materi-materi tersebut tidak saling berkaitan. Kelima belas mahasiswa tersebut belum menyadari bahwa konsep-konsep yang diperoleh saat mengikuti mata kuliah konten matematika dasar akan melatih cara berpikir dan memperkuat konsep dasar matematika yang dimiliki mahasiswa.

Hasil penelitian Maryono (2016) menyatakan bahwa mahasiswa calon guru dengan kemampuan akademik sangat baik dan baik memiliki pengetahuan konten, pengetahuan mengajar, dan pengetahuan siswa yang relatif sama, yaitu pada level 1 sampai level 2. Ini berarti, kemampuan akademik pun memiliki kontribusi bagi keterampilan dasar mengajar calon guru.

\section{Kemampuan pedagogik dan keterampilan dasar mengajar}

Hasil uji korelasi yang nampak pada Tabel 5 menunjukkan bahwa terdapat korelasi yang signifikan antara skor kemampuan akademik dan keterampilan dasar mengajar dengan koefisien korelasinya sebesar 0,350. Nilai ini termasuk ke dalam korelasi lemah (Sugiyono, 2014). Sementara hasil pada Tabel 6 yang menyatakan bahwa terdapat pengaruh yang signifikan dari kemampuan pedagogik terhadap keterampilan dasar mengajar. Artinya, keberhasilan mahasiswa dalam pedagogik memberikan pengaruh positif terhadap keberhasilan mahasiswa dalam micro teaching.

Lebih lanjut dari hasil kuesioner, mahasiswa menyadari bahwa mata kuliah Pedagogi (baik Pedagogi 1, Pedagogi 2, maupun Pedagogi 3) membekali mahasiswa dalam: (1) menyusun rencana pembelajaran (RPP); (2) menentukan strategi, metode, dan teknik pembelajaran yang baik dan sesuai untuk digunakan dalam pembelajaran; (3) memanajemen kelas; (4) bersikap, bertindak, dan menjelaskan materi di dalam proses pembelajaran; (5) menentukan teknik penilaian yang tepat, dan menyusun instrumen serta rubrik penilaian; serta (6) mengetahui kemampuan matematis apa saja yang perlu dikuasai siswa.

Hasil ini sejalan dengan kompetensi pedagogik yang merupakan salah satu kompetensi yang juga perlu dimiliki oleh seorang guru. Kompetensi pedagogik merupakan "kemampuan guru dalam mengelola pembelajaran yang mencakup pemahaman dan pengembangan peserta didik; serta perencanaan, pelaksanaan dan evaluasi kegiatan pembelajaran" (Dirgantoro, 2018). Guru yang memiliki kompetensi pedagogik akan mampu melaksanakan tugasnya dengan baik (Nabila, 2016). Sejalan dengan pernyataan tersebut, Suciu \& Mata (2011) 
menyatakan bahwa kompetensi pedagogik merupakan salah satu kompetensi kunci yang perlu dimiliki guru untuk dapat menciptakan pendidikan yang berkualitas.

\section{Simpulan dan Saran}

\section{Simpulan}

Simpulan dari penelitian ini adalah: (1) terdapat korelasi yang signifikan antara kemampuan akademik dan keterampilan dasar mengajar mahasiswa Pendidikan Matematika FIP UPH, di mana korelasi tergolong sedang yang berarti semakin tinggi kemampuan akademik maka semakin tinggi pula keterampilan dasar mengajar mahasiswa; (2) terdapat pengaruh yang signifikan dari kemampuan akademik terhadap keterampilan dasar mengajar yang berarti keberhasilan mahasiswa dalam akademik memberikan pengaruh positif terhadap keberhasilan mahasiswa dalam micro teaching; (3) terdapat korelasi yang signifikan antara kemampuan pedagogik dan keterampilan dasar mengajar mahasiswa Pendidikan Matematika FIP UPH, di mana korelasi tergolong lemah; serta (4) terdapat pengaruh yang signifikan dari kemampuan pedagogik terhadap keterampilan dasar mengajar yang berarti keberhasilan mahasiswa dalam pedagogik memberikan pengaruh positif terhadap keberhasilan mahasiswa dalam micro teaching. Ini artinya, kemampuan akademik dan kemampuan pedagogik merupakan faktor yang dapat menentukan keberhasilan guru dalam mengajar siswa.

\section{Saran}

Keterampilan dasar mengajar
merupakan keterampilan yang dibutuhkan mahasiswa calon guru, oleh karenanya perlu dilatih terus menerus agar mahasiswa calon guru lebih siap untuk bisa terjun langsung ke dalam kelas. Penelitian ini pun dapat dilanjutkan untuk melihat apakah ada peningkatan keterampilan dasar mengajar mahasiswa saat mengikuti mata kuliah PSAP Matematika Sekolah Menengah, serta saat mahasiswa mengikuti kegiatan praktek lapangan (PPL).

\section{Daftar Pustaka}

Asril, Z. (2016). Micro teaching. Jakarta: PT Raja Grafindo Persada.

Barlian, I. (2013). Begitu pentingkah strategi belajar mengajar bagi guru? Jurnal Forum Sosial, 6(1), 241-246. Diakses dari:

http://eprints.unsri.ac.id/2268/2/isi.pdf

Dirgantoro, K. (2018). Kompetensi guru matematika dalam mengembangkan kompetensi matematis siswa. Scholaria: Jurnal Pendidikan dan Kebudayaan, $8(2)$, 157-166. https://doi.org/https://doi.org/10.24246/j .js.2018.v8.i2.p157-166

Herman, T. (2010). Aktivitas dalam pembelajaran matematika di sekolah dasar. Diakses tanggal 4 Mei 2019 dari:http://file.upi.edu/Direktori/FPMIP A/JUR._PEND._MATEMATIKA/1962 10111991011TATANG_HERMAN/Artikel/Artikel19 .pdf

Karim, A. (2011). Penerapan metode penemuan terbimbing dalam pembelajaran matematika untuk meningkatkan pemahaman konsep dan kemampuan berpikir kritis siswa sekolah dasar. Diakses dari: http://jurnal.upi.edu/file/3Asrul_Karim.pdf 
Mahmud, I. \& Rawshon, S. (2013). Micro teaching to improve teaching method: an analysis on students' perspectives. IOSR Journal of Research \& Method in Education (IOSR-JRME, 1(4), 69-76. Diakses dari: http://iosrjournals.org/iosrjrme/papers/Vol-1\%20Issue$\underline{\text { 4/J0146976.pdf }}$

Maryono. (2016). Penerapan pedagogical content knowledge (PCK) mahasiswa calon guru matematika ditinjau dari kemampuan akademiknya. JRPM (Jurnal Review Pembelajaran Matematika), 1(1), 1-16. https://doi.org/10.15642/jrpm.2016.1.1. $\underline{1-16}$

Mergler, A.G. \& Tangen, D. J. (2010). Using microteaching to enhance teacher efficacy in pre-service teachers. Teaching Education, 21(2), pp. 199-210. https://doi.org/10.1080/1047621090299 8466

Nabila, H. (2016). The Influence of Pedagogic Competence and Professional Competence to Performance of Teachers Social Studies in Trowulan District. International Conference on Ethics of Business, Economics, and Social Science yang diselenggarakan oleh Fakultas Ekonomi UNY, tanggal 16-17 September 2016. Yogyakarta: Universitas Negeri Yogyakarta.

Raharja, S., Wibhawa, M. R., \& Lukas, S. (2018). Mengukur rasa ingin tahu siswa. Polyglot: Jurnal Ilmiah, 14 (2), 151-164. http://dx.doi.org/10.19166/pji.v14i2.832

Şen, A.I. (2009). A study on the effectiveness of peer microteaching in a teacher education program. Journal of Science and Mathematics Education, 34 (151), 165-174. Retrieved from: http://egitimvebilim.ted.org.tr/index.php /EB/article/viewFile/616/119

Siregar, N. (2017). Persepsi siswa pada pelajaran matematika: studi pendahuluan pada siswa yang menyenangi game.
Disampaikan pada Prosiding Tети Ilmiah $X$ Ikatan Psikologi Perkembangan Indonesia, 22-24 Agustus 2017, Hotel Grasia, Semarang. 224-232. Diakses dari: http://jurnal.unissula.ac.id/index.php/ipp i/article/download/2193/1655

Siswanto. (2010). Tingkat penguasaan keterampilan dasar mengajar mahasiswa prodi. Pendidikan akuntansi fakultas ilmu sosial dan ekonomi universitas negeri yogyakarta. Jurnal Pendidikan Akuntansi Indonesia, 8(2): 41-51. http://dx.doi.org/10.21831/jpai.v8i2.953

Suciu, A. \& Mata, L. (2011). Pedagogical competences-the key to efficient education. International Online Journal of Educational Sciences, 2011, 3(2), 411423.

Sugiyono. (2014). Metode penelitian pendidikan: pendekatan kuantitatif, kualitatif, dan $r \&$ d. Bandung: Alfabeta.

Suyono. (2018). Analisis Regresi untuk Penelitian. Yogyakarta: Deepublish.

Wijarini, F. \& Ilma, S. (2017). Analisis keterampilan mengajar mahasiswa jurusan pendidikan biologi universitas borneo tarakan sebagai calon guru melalui kegiatan PPL. Jurnal Pendidikan Biologi Indonesia, 3(2), 149-159. https://doi.org/10.22219/jpbi.v3i2.4311

Yusuf, M. (2014). Metode Penelitian: Kuantitatif, Kualitatif, dan Penelitian Gabungan. Jakarta: Kencana. 